\title{
Physical Activity Epidemiology of University Students
}

Gabriel Gastélum-Cuadras

Universidad Nacional Autonoma de Mexico

TOMIRES CAMPOS LOPES ( $\square$ tiotom10@yahoo.com.br)

Universidade Federal de Mato Grosso https://orcid.org/0000-0002-4532-7045

Artur Luís Bessa de Oliveira

Universidade Federal de Mato Grosso

Carlos Soares Pernambuco

Universidade Estacio de Sa

Paula Paraguassú Brandão

Universidade Federal do Estado do Rio de Janeiro

Andréa Carmen Guimarães

Universidade Tiradentes

Maria de Nazaré Dias Bello

Centro Universitario do Estado do Para

Michael Douglas Celestino Bispo

Universidade Tiradentes

Leila Castro

Universidade Federal do Para

Mauro Cesar Gurgel de Alencar Carvalho

Colegio Pedro II

João Rafael Valentim-Silva

Universidade Federal de Rondonia

Estélio Henrique Martin Dantas

Universidade Federal do Estado do Rio de Janeiro

\section{Research article}

Keywords: Epidemiology, Physical activity, University Student, Lifestyles

Posted Date: July 16 th, 2020

DOI: https://doi.org/10.21203/rs.3.rs-39481/v1

License: @ (i) This work is licensed under a Creative Commons Attribution 4.0 International License. Read Full License 


\section{Abstract}

Background

Moderate and vigorous physical activity is essential to maintain proper body composition and reduce the risk of ischemic heart disease, diabetes and cancer. In addition, it reduces the risk of stroke, hypertension and depression. Even so, it is an essential determinant of energy expenditure and, therefore, fundamental for energy balance and weight control. The objective of this epidemiological study is twofold: to quantify and qualify the physical activity of students at a federal public university in the Brazilian Midwest and to compare the level of physical activity of incoming and senior students, by sex and by campuses, considering the distance from large centers population.

Method

A questionnaire adapted for the Brazilian population was used, whose results were subjected to a normality test and the differences between groups were compared. Statistical significance was set at $\mathrm{p}<0.05$. All results are presented as mean and standard deviation.

Results

18,986 students enrolled on the 5 UFMT campuses, 9,720 students accessed the questionnaire. Of these, 7,379 had their answers validated, corresponding to $75.92 \%$ of accesses or $38.87 \%$ of the universe studied. This study found differences in the level of physical activity among university students, observing less physical activity on the Rondonópolis campus, less physical activity of students in the areas of Linguistics and Humanities, when compared with students from other areas, less physical activity of female students. when compared to male students and less physical activity among enrolled students compared to undergraduate students.

Conclusions

The results suggest the need for greater investment in policies to promote physical activity among university students in all fields.

\section{Background}

Physical activity includes exercise as well as other activities involving body movement and is performed as part of play, work, active transportation, household chores and recreational activities. The term exercise, in turn, is characterized by "physical activity that is planned, structured, repetitive, and purposeful in the sense that the improvement or maintenance of one or more components of physical fitness is the objective"(WORLD HEALTH ORGANIZATION, 2018b).

Moderate and vigorous physical activity is essential to maintain an adequate and healthy body composition (ARIGO e colab., 2017). According to the World Health Organization (WHO) (SALUD, 2018), physical activity for practitioners older than 18 years "reduces the risk of ischaemic heart disease, diabetes, breast and colon cancer. Additionally, it lowers the risk of stroke, hypertension, and depression." As stated by the organization, "physical activity is a key determinant of energy expenditure and thus fundamental to energy balance and weight control."

According to the WHO, the minimum time of physical activity required for these benefits to be achieved by adults is 150 minutes per week of moderate physical activity or at least 75 minutes of intense activity or a combination of both. However, for greater benefits, adults should perform 300 minutes of moderate or equivalent activity per week, in addition to muscle strengthening activities on 2 or more days per week, exercising large muscle groups (WORLD HEALTH ORGANIZATION, 2011).

Based on this knowledge, the WHO highlights the need to increase physical activity in the world population through an action plan related to noncommunicable diseases for the period from 2013 to 2020 (WORLD HEALTH ORGANIZATION, 2013) and the 2030 Agenda for Sustainable Development (ASAMBLEA GENERAL DE LAS NACIONES UNIDAS, 2015). The statements of intentions predict a relative reduction of $10 \%$ in the prevalence of insufficient physical activity by 2025 and of $15 \%$ by 2030 as 1 of the 9 global goals to improve the prevention and treatment of noncommunicable diseases.

Current studies conducted by the WHO itself reveal that these efforts were not effective because the levels of inactivity have been very high worldwide (WORD HEALTH ORGANIZATION, 2019). Another study revealed that in 55 (33\%) of 168 countries, more than one-third of the population does not practice sufficient physical activity. In 4 countries, more than half of the adults are insufficiently active: Kuwait (67\%), American Samoa (53\%), Saudi Arabia (53\%) and Iraq (52\%). The countries with the lowest levels of physical activity are Uganda and Mozambique (6\% each) (GUTHOLD e colab., 2018).

Regarding Brazil, from 2013 to 2017, there was a decrease of 1.02\% per year in the frequency of insufficient physical activity among women. However, indicators of obesity evolved. The frequency of overweight adults increased on average $1.14 \%$ per year and $0.67 \%$ per year, and following this trend, the frequency of individuals diagnosed with diabetes increased on average $0.24 \%$ per year (BRASIL e SAÚDE, 2018).

The problems resulting from global physical inactivity are related to metabolic syndrome (BARBOSA e colab., 2016), overweight (LEE e colab., 2017; MARQUES e colab., 2017), and dementia (SALLIS e colab., 2016), among others (CARVALHO e colab., 2015).

Population-based studies on physical activity or inactivity of undergraduate students are not standardized, and thus, the results are unable to be applied to other realities; however, the results follow the trends representative of society at large.

Studies comparing the practice of physical activity showed that there is a higher prevalence among male students in different countries of the world (FAGARAS e colab., 2015; SANTOS, Tiago e colab., 2017) but a low level of practice. The main barriers have been attributed to long study hours, lack of 
energy/fatigue, and lack of company in different programs analyzed (NASCIMENTO e colab., 2017; PINTO e colab., 2017), as well as difficulties in the use of bicycles for student transport and, thus, in the maintenance of physical activity (YUAN e colab., 2017).

The Federal University of Mato Grosso is located far from the main Brazilian population centers and has five campuses spread over three different brazilian ecosystems, which all have different characteristics. To assess under these specific conditions if academics adopt physical activities during their academic life is a necessary enterprise for the accurate development of public policies.

The objective of this epidemiological study is twofold: To quantify and to qualify the physical activity of students at the Federal University of Mato Grosso (UFMT) and to compare the level of physical activity of entering and graduating students.

\section{Methods}

This was a descriptive observational study of the health risk behavior of university students from the 5 UFMT campuses conducted in the 2018/1 academic semester. For data collection, an electronic link was provided on the page of all students that directed them to the National College Health Risk Behavior Survey (NCHRBS) used by the Centers for Disease Control and Prevention (CDC), which has been used to monitor health risk behaviors of adolescents and youth in the United States since 1991. Upon accessing the link, the student read the informed consent form and made a choice to participate or not in the study. After agreeing to participate, the participant completed the survey. The questionnaire was adapted and validated for use with Brazilian university students by Franca and Colares in 2010 (FRANCA e COLARES, 2010) and applied in Google Docs format. The study was approved by the Ethics Committee of UNIRIO under CAAE No. 79742117.0.0000.5285.

The instrument used comprises 51 questions, but the present study only addressed the aspect related to physical activity. For this question, 8 alternatives were presented regarding the number of times that the students performed physical activity during the week, ranging from none to 7 times. As physical inactivity is a risk behavior to be avoided, the highest value was assigned to the option where physical activity is less practiced, while the value 1 represented the highest possible number of times the student practices physical activity. Thus, a value of 1 was assigned to 7 times, 2 to 6 times, 3 to 5 times and so on up to for no physical activity.

Data were assessed for normality of distribution using the Kolmogorov-Smirnov test and showed a nonparametric distribution. The differences between groups were determined by Kruskal-Wallis followed by Dunn's post hoc test when comparing 3 or more groups or by the Mann-Whitney rank sum test when comparing 2 groups. Statistical significance was set up at 0.05 . All results are presented as the mean and standard deviation.

\section{Results}

All treatments were performed using a confidence level of $99 \%(p=0.01)$ or $95 \%(p=0.05)$. Therefore, from a total of 18.986 subjects presents in the referred institution, it is the universe, was calculated the " $n$ " of 3.402 subjects to $99 \%$ of confidence. Here, were taken 7.379 volunteers which warrant a Power of Experiment of $98,83 \%$ a very high level. If taken separately, to the Araguaia Campus, from universe of 2.494 people, the calculated " $n$ " was of 733 subjects, however, were used 805 which warranted an experiment power of 96.36\%. To Cuiabá Campus, with Universe of 10157, the " $n$ " was calculated in 3.945, were used 4152 warranting an experiment power calculated in $98.46 \%$. In regards, the Rondonópolis Campus, with a universe composed by 3.739 students the calculated " $n$ " was 910 subjects, was reached 914 subjects and the experiment power calculated were of $96.98 \%$. Finally, the last campus investigated was Várzea Grande, with universe composed by 761 , and calculated " $n$ " of 322 to $95 \%$ of confidence, and, here participated exactly 322 which allowed calculi the experiment power of $95,85 \%$. This conjunct of data, if taken together, allow to conclude that the results and conclusion are very robustly supported to the statistical methods here displayed.

Of the 18,986 students enrolled in the 5 UFMT campuses in the $2018 / 1$ semester, 9.720 students accessed the questionnaire. Of these, 7.379 had their responses validated, corresponding to $75.92 \%$ of accesses or $38.87 \%$ of the study universe. Table 1 shows the sample composition divided among campuses. Sinop, women and beginners present themselves with a higher percentage of participation in the research, followed by Rondonópolis and Cuiabá. However, the largest absolute number of participants was observed in the state capital, Cuiabá.

Table 2 shows the distribution of participants by areas of knowledge on all campuses, which follows the methodology adopted by the Coordination for the Improvement of Higher Education Personnel - CAPES (BRASIL; CAPES, 2017), of the Ministry of Education of Brazil (MEC). Altogether, data from eight areas of knowledge were considered, based on existing courses at UFMT. The courses distribution does not happen on an equal basis in all campuses, as it depends on the vocation of each region where the campuses are installed. It is noted the predominance of student participation in the area of Applied Social Sciences, followed by Human Sciences and Engineering, while low adherence in the areas of Linguistics and Arts.

With regard to the number of physical activity was performed per week, physical exercise was defined as participation in sports activities for at least 20 minutes, causing the student to sweat and breathe hard, such as basketball, jogging, swimming, tennis, weight training, cycling or similar aerobic activities. The student could select one of the alternatives provided in the questionnaire, which was presented as a Likert scale ranging from zero to 7 times. Table 3 shows the distribution of the absolute numbers and percentages for this variable across all campuses. The distribution frequency of practice by strata reveals little physical activity on all campuses, since the highest percentages are in decreasing form in the number of times that the academic exercises and the highest rates are only once in all.

Figure 1 shows the distribution of means of physical activity on each of the campuses. Here, were noted differences among the Rondonópolis vs Araguaia ( $\mathrm{p}$ $=0.0008)$, vs Cuiaba $(p=0.037)$, and vs Sinop $(p=0.0167)$. All other comparison do not exhibit differences. 
When comparing the campuses, the results show physical inactivity in the four realities: the number of times physical activity was performed per week was approximately 2 times. On the Rondonópolis campus, there is a higher frequency of students with a low number of weekly physical activity sessions, while on the Cuiabá campus, the number of weekly physical activity sessions was highest, with a statistically significant difference between the 2 campuses.

Figure 2 shows the results of the comparisons between the study areas of all campuses. Notably, no comparisons were made between the study areas of the Várzea Grande campus, because it currently offers only Engineering programs.

In the comparative analysis between the study areas of each of the campuses, a low number of weekly sessions of physical activity was common, with significant differences only between the Cuiabá and Rondonópolis campuses. In Cuiabá, students in the areas of Health Sciences, Exact Sciences and Engineering showed higher levels of physical activity, with significant differences between the areas of Humanities and Linguistics, and students of Health Sciences were more active than those of Sciences Social Sciences, Agrarian Sciences and Biological Sciences. On the Rondonópolis campus, the same results were observed, as students in the areas of Health Sciences and Engineering were statistically more active than those in the area of Linguistics. The Araguaia and Sinop campuses, despite the low number of weekly sessions of physical activity, did not show significant differences between the study areas.

In regard to the Araguaia and Sinop campuses no differences were observed ( $p>0.05$ ) (Fig. 2A and 2C). To the Cuiabá campus the health area did difference to Social area $(p=0.0092)$, Agricultural, Biological $(p=0.0001)$, Humanities $(p=0.0001)$, and Linguistics areas $(p=0.0001)$. Rondonópolis campus display difference from Linguistics area to Health area $(p=0.0003)$, to Social area $(p=0.0007)$, and to Engineering area $(p=0.0001)$.

Based on the findings displayed in the Fig 2, we analyzed the possibility of differences between programs in the fields with the highest levels of physical inactivity on the Cuiabá and Rondonópolis campuses. Figure 3 shows the comparison between the Humanities and Linguistics programs.

In regards the treated in the Fig. 3 no differences were noted ( $p>0.05)$ for all treatments. The results show that on the Cuiabá campus, in the Humanities fields, student in the Philosophy - Bachelor's, morning History and morning and evening Pedagogy programs performed nearly no physical activity, and students in the other programs also participated in a low number of weekly physical activity sessions, 1 to zero times per week. In Linguistics, the students in the language and literature programs reported very little physical activity, with Spanish language being particularly concerning; in the Arts field, students in the Cinema and Radio programs participated in very few physical activity sessions. On the Rondonópolis campus, students in the 2 Linguistics programs reported low levels of physical activity, with students in the Portuguese Language program reporting the highest levels of physical inactivity. No significant differences were found between the programs in the fields studied for the 2 campuses.

Regarding the graduation stage, the possible differences in the amount of physical activity by students at admission and graduation may reveal characteristics acquired during their life as a university student. Thus, Table 4 shows a comparison of the number of weekly physical activity sessions for entering and graduating students. Figure 4 shows a comparison of physical activity among entering and graduating students.

The data per campus in the comparative analysis between entering and graduating students did not indicate a clear pattern regarding the number of physical activity sessions, and the same was true when comparing the campuses among each other. That is, the students on each campus behave differently for each variable. However, for absolute inactivity, entering students were predominant, with the exception of those on the Sinop campus. When considering physical activity 2 and 3 times a week, the graduating students predominated.

Here, in the Fig 4, stood evident that the graduating students in comparison with the entering students has less physical inactivity $(p=0.0005)$.

Figure 5 shows a comparison of the mean weekly physical activity sessions between entering and graduating students within the Capes fields of study at each of the campuses. Here were performed several comparisons. The data revealed that on the Araguaia campus, there were no differences when the fields of study were compared among each other, but there were differences between entering and graduating students in the Exact Sciences field. In Cuiabá, in turn, there were differences between the entering students of the Social Sciences field and the graduating students of the Health Sciences field and between the entering and graduating students of the Health Sciences field. The other campuses did not show differences between fields of study and between groups of entering and graduating students.

The Fig 5A an intracampuses investigation revel difference among entering vs graduating students of Araguaia campus $(p=0.0001)$, Cuiabá ( $p=0.0051)$, and, to General analysis $(p=0.0001)$, without other difference observed. The Fig $5 B$ that exhibit an intercampuses comparison no differences were noted ( $p>0.05$ ). In regard the Fig $5 \mathrm{C}$ about the Araguaia campus, Fig 5D Cuiabá campus, Fig 5E Rondonópolis campus and 5F Sinop campus that are exhibited the comparison among entering and graduating students no differences were noted to all comparisons $(p>0.05)$.

To understand how participation in physical activity behaves, it is important to consider how both genders behave on all campuses. Figure 6 shows a comparison by gender for campuses and overall. The data unanimously showed low physical activity among women overall and on all campuses, with significant differences in all comparisons. When all campuses were analyzed together, women showed significant physical inactivity, at a higher level than that reported by men overall and by men on the Cuiabá and Sinop campuses.

\section{Discussion}

The regular practice of physical activity has several benefits, which has already been described in the literature (DOYLE e colab., 2019; MALM e colab., 2019; MANFERDELLI e colab., 2019; STEPHENS e colab., 2019; VERT e colab., 2019; WORLD HEALTH ORGANIZATION, 2018a) This indicates the relevance of conducting a population survey on the practice of physical activity among UFMT students and identifying whether lifestyles adopted during the university period influence the practice of physical activity. 
UFMT undergraduate students practice less physical activity than the 2 or more days per week recommended by the WHO (WORD HEALTH ORGANIZATION, 2018). In an evaluation among the campuses, significantly below the overall UFMT average. However, poor levels of physical activity have been reported by several other studies. In 2016, 379 university students in Cali, Colombia, were analyzed (VARELA-ARÉVALO e colab., 2016a, b), showing the existence of groups of male and female students with unhealthy physical activity practices, regardless of whether they were working (CALESTINE e colab., 2017), observed sedentary behavior and obesity in 512 students in the United States and related it to the excessive use of social media. The same phenomenon was observed in Brazil, where a study in the Northeast region found a 52\% prevalence of sedentary lifestyle in a sample of 605 students (MARTINS e colab., 2010); $30.8 \%$ of students in a sample from the Southern region also exhibited an insufficient level of physical activity (SILVA e PETROSKI, 2011).

Similar to our study, other authors also found higher physical inactivity among females (ALZAMIL e colab., 2019; DAVIS e colab., 2017; OLFERT e colab., 2019; TOWNE e colab., 2017) with a consequent increase in the rates of (KRISHNAMOHAN e colab., 2017; LEE e colab., 2017; MARQUES e colab., 2017) obesity (ZHANG e colab., 2018), diabetes mellitus, hypercholesterolemia, metabolic syndrome and hypertension. (TURI e colab., 2016).

Comparing the fields of study of the UFMT undergraduate programs, for the Health Sciences field, the number of weekly physical activity sessions among students was statistically higher on the Cuiabá and Rondonópolis campuses, which housed $31.72 \%$ of the total students evaluated. These results are consistent with those from others studies, such as one conducted in Brazil that reported a good level of physical activity in Physical Education, Physical Therapy, Nursing and Nutrition students (NASCIMENTO e colab., 2017).

To understand the effect of the university lifestyle on engaging in sedentary risk behavior, we compared entering and graduating students, and we observed that the university experience had a positive impact because the graduating students participated in physical activity more so than entering students. This result is not consistent within the published literature, as our study agrees with the findings of a study conducted in Piauí I which entering students were found to be more sedentary than were graduating students (SANTOS, Leianny Rodrigues Dos e colab., 2014) and with a study conducted in Amazonas in which graduating students were more adept at physical activity than were entering students (PRATA NOGUEIRA e colab., 2014) but diverges from the findings of another done in Brazil with a sample size of 1,599 students from Paraná, found that graduating students were those most likely to have insufficient physical activity (GASPAROTTO e colab., 2013). Abroad, the results from an American study showed a low level of physical activity among female college freshmen (BUTLER e colab., 2004); a more recent study conducted in the United States also revealed barriers to exercise such as lack of time, energy and strength of will in male and female students classified as traditional or non-traditional (BALL e colab., 2018); and finally, in the United States, a different study did not show differences between entering and graduating students regarding participation in intramural physical activity (COWEN e colab., 2018).

\section{Conclusion}

This study found differences in the level of physical activity among university students, observing lower physical activity by university students on the Rondonópolis campus, lower physical activity by students in the Linguistics and Humanities fields, when compared with that by students in the other fields, lower physical activity by female students compared with that by male students, and lower physical activity by entering students compared with that by graduating students. Given the results obtained, there is a need for greater investment in policies for promoting physical activity among university students in all fields so that the intensity of physical activity is equal to or higher than the levels recommended for individuals over 18 years of old, especially among women, and for creating mechanisms for adherence to physical activity upon admission on all university campuses.

The strengths of our study include a large sample size, the range of coverage of the state territory that encompasses 3 ecosystems, and the crossing of information by field, by program and by graduation stage, which has not been addressed in other studies.

\section{Abbreviations}

World Health Organization - WHO

Federal University of Mato Grosso - UFMT

Centers for Disease Control and Prevention - CDC

Certificate of Presentation of Ethical Appreciation - CAAE

Coordination for the Improvement of Higher Education Personnel - CAPES

Ministry of Education of Brazil - MEC

\section{Declarations}

- Ethics approval and consent to participate: All participants were informed of the right to refuse to participate. Upon accessing the link, the student read the Informed Consent Form (ICF) and chose to participate or not in the research. In case of acceptance, they signed the CIF digitally. The research was approved by the Research Ethics Committee of the Federal University of Rio de Janeiro and met all the ethical principles that govern research with human beings, determined by Resolution 466, of December 2012, of the National Health Council (CNS).

- Consent for publication: Not applicable

- Availability of data and materials: The datasets used and/or analysed during the current study are available from the corresponding author on reasonable request. 
- Competing interests: The authors declare that they have no competing interests

- Funding: The work did not receive funding for its development and completion.

- Authors' contributions: GGC contributed to the preparation of the study and translation of the article. TCL conducted the research. ALBO co-supervised the work and was a major contributor to the writing of the manuscript. CSP, PPB, ACG, MNDB worked on the analysis and discussion. LC, MCGA worked on the theoretical contribution. The JRVS treated the data statistically. The EHMD guided the work. All authors read and approved the final manuscript.

- Acknowledgements: The authors would like to thank the Federal University of Mato Grosso for allowing this research to be carried out through its own institutional communication system.

- Authors' information (optional)

Gabriel Gastélum-Cuadras ${ }^{1,2}$, Tomires Campos Lopes ${ }^{3}$, Artur Luís Bessa de Oliveira ${ }^{3}$, Carlos Soares Pernambuco ${ }^{4}$, Paula Paraguassú Brandão $5,4,6$, Andréa Carmen Guimarães ${ }^{7,8}$, Maria de Nazaré Dias Bello ${ }^{9}$, Michael Douglas Celestino Bispo ${ }^{7}$, Leila Castro ${ }^{9}$, Mauro Cesar Gurgel de Alencar Carvalho ${ }^{10}$, João Rafael Valentim-Silva ${ }^{11,12,13}$, Estélio Henrique Martin Dantas $5,7,2$, on behalf of Human Motricity Biosciences Laboratory (LABIMH).

1 - Program in Physical Culture Sciences, School of Physical Culture Sciences. Autonomous University of Chihuahua. Desalud Dermatoglifia A.C (Sports, Health and Dermatoglyphics). Chihuahua, Chihuahua, Mexico.

2 - International Human Motricity Network (IHMN).

3 - Federal University of Mato Grosso - School of Physical Education, Department of Physical Education, Cuiabá, Mato Grosso, Brazil.

4 - Estácio of Sá University, Campus Cabo Frio/RJ Brazil, Physiology of exercise Laboratory, Cabo Frio, Rio de Janeiro, Brazil.

5 - Postgraduate Program in Nursing and Biosciences - PPgEnfBio, Federal University of the State of Rio de Janeiro - UNIRIO, Rio de Janeiro, Brazil.

6 - Celso Lisboa University, Rio de Janeiro, Brazil.

7 - Postgraduate Program in Health and Environment - PSA, Tiradentes University - UNIT, Aracaju, Sergipe, Brazil.

8 - Department of Physical Education in Health - DCEFS - Graduate Program in Psychology - UFSJ, Study Group on Physical Activity and Health - GEAFS. Federal University of São João del Rei - UFSJ, Study Group on Physical Activity and Health - GEAFS, Minas Gerais, Brazil.

${ }^{9}$ State Department of Education of Pará, Belém, Pará, Brazil.

10 - Pedro II School - Campus São Cristóvão II, Rio de Janeiro, Brazil.

11 - Biotechnology Laboratory of the Oswaldo Cruz Foundation, Department of Physical Education, Federal University of Rondônia, Porto Velho, Rondônia;

12 - Post-Doctorate at the Nanobiotechnology Laboratory at the Federal University of Acre, Brazil

13 - Department of Physical Education at University Center UNINORTE, Rio Branco, Acre, Brazil.

\section{References}

1. ALZAMIL, Hana A. e colab. A Profile of Physical Activity, Sedentary Behaviors, Sleep, and Dietary Habits of Saudi College Female Students. Journal of Family and Community Medicine, v. 26, n. 1, p. 1-4, 2019.

2. ARIGO, Danielle e colab. Psychosocial Predictors of Physical Activity Change among College Students in an Obesity Prevention Trial. J Phys Act Health, v. 14, n. 7, p. 513-519, 2017.

3. ASAMBLEA GENERAL DE LAS NACIONES UNIDAS. Agenda 2030 para el Desarrollo Sostenible. Organización Mundial de la Salud. [S.I: s.n.], 2015.

4. BALL, James W. e BICE, Matthew R. e MALJAK, Kimberly A. Exploring the Relationship Between College Students' Barriers to Exercise and Motivation. American Journal of Health Studies, v. 33, n. 2, p. 61-69, 2018.

5. BARBOSA, José Bonifácio e colab. Metabolic syndrome, insulin resistance and other cardiovascular risk factors in university students. Ciência \& Saúde Coletiva, v. 21, n. 4, p. 1123-1136, 2016.

6. BRASIL e SAÚDE, Ministério Da. Vigitel Brasil 2017. (Ministério da Saúde, Org.). Brasília, DF: [s.n.], 2018.

7. BUTLER, Scott M e colab. Change in Diet, Physical Activity, and Body Weight in Female College Freshman. Am J Health Behav, v. 28, n. 1, p. $24-32,2004$.

8. CALESTINE, Jesse e colab. College Student Work Habits are Related to Physical Activity and Fitness. International journal of exercise science, v. 10, n. 7, p. 1009-1017, 2017.

9. CARVALHO, Carolina Abreu De e colab. Associação entre fatores de risco cardiovascular e indicadores antropométricos de obesidade em universitários de São Luís, Maranhão, Brasil. Ciência \& Saúde Coletiva, v. 20, n. 2, p. 479-490, 2015.

10. COWEN, Elenna R. e colab. An examination of intramural college students' exercise motives and how they relate to body mass index. American Journal of Health Studies, v. 33, n. 4, p. 187- 195. 9p, 2018. 
11. DAVIS, Heather A. e colab. Alcohol use and strenuous physical activity in college students: A longitudinal test of 2 explanatory models of health behavior. J Am Coll Health, v. 65, n. 2, p. 112-121, 2017.

12. DOYLE, CB e KHAN, A e BURTON, NW. Knowledge of physical activity guidelines and mental health benefits among Emirati university students. Perspectives in Public Health, v. XX, n. XI, 2019. Disponível em: <https://journals.sagepub.com/doi/pdf/10.1177/1757913919834060>. Acesso em: 1 ago 2019.

13. FAGARAS, Simona-Pia e RADU, Liliana-Elisabeta e VANVU, Gynetta. The Level of Physical Activity of University Students. Procedia - Social and Behavioral Sciences, v. 197, n. February, p. 1454-1457, 2015. Disponível em: <http://dx.doi.org/10.1016/j.sbspro.2015.07.094>.

14. FRANCA, Carolina Da e COLARES, Viviane. Validação do National College Health Risk Behavior Survey para utilização com universitários brasileiros Ciência \& Saúde Coletiva, v. 15, n. suppl 1, p. 1209-1215, Jun 2010.

15. GASPAROTTO, Guilherme da Silva e colab. Associação entre o período de graduação e fatores de risco cardiovascular em universitários. Rev. Latino-Am. Enfermagem, v. 21, n. 3, 2013. Disponível em: <www.eerp.usp.br/rlae>.

16. GUTHOLD, Regina e colab. Worldwide trends in insufficient physical activity from 2001 to 2016: a pooled analysis of 358 population-based surveys with 1.9 million participants. The Lancet Global Health, v. 6, n. October, p. e1077-e1086, 2018.

17. KRISHNAMOHAN, Smrithi e colab. Efficacy of health education using Facebook to promote healthy lifestyle among medical students in Puducherry, India: A non-randomized controlled trial. Journal of Clinical and Diagnostic Research, v. 11, n. 7, p. LC07-LC10, 2017.

18. LEE, Jounghee e colab. Body-related Perspectives and Weight Control Methods of Korean-Chinese Nursing School Students in Yanbian, China: A Pilot Study. Osong Public Health and Research Perspectives, v. 8, n. 4, p. 275-281, 2017.

19. MALM, Christer e JAKOBSSON, Johan e ISAKSSON, Andreas. Physical Activity and Sports-Real Health Benefits: A Review with Insight into the Public Health of Sweden. Sports, v. 7, n. 127, 2019. Disponível em: <www.fyss.se>. Acesso em: 1 ago 2019.

20. MANFERDELLI, Giorgio e LA TORRE, Antonio e CODELLA, Roberto. Outdoor physical activity bears multiple benefits to health and society. The Journal of Sports Medicine and Physical Fitness, v. 59, n. 5, p. 23736, 2019.

21. MARQUES, Andréa e BARBOSA, Marileisa e GUEDES, Dartagnan. Exercise and fruit/vegetable intake in a sample of Brazilian university students: association with nutritional status. Revista Brasileira de Atividade Física \& Saúde, v. 22, n. 2, p. 165-175, 2017.

22. MARTINS, Maria do Carmo de Carvalho e e colab. Pressão arterial, excesso de peso e nível de atividade física em estudantes de universidade pública. Arquivos Brasileiros de Cardiologia, v. 95, n. 2, p. 192-199, 2010.

23. NASCIMENTO, Tiago e ALVES, Felipe e SOUZA, Evanice. Barreiras percebidas para a prática de atividade física em universitários da área da saúde de uma instituição de ensino superior da cidade de Fortaleza, Brasil. Revista Brasileira de Atividade Física \& Saúde, v. 22, n. 2, p. $137-146,2017$.

24. OLFERT, Melissa D. e colab. Sex differences in lifestyle behaviors among U.S. college freshmen. International Journal of Environmental Research and Public Health, v. 16, n. 3, 2019.

25. PINTO, Andre de Araujo e colab. Barreiras percebidas para a prática de atividade física entre universitários de Educação Física. Revista Brasileira de Atividade Fisica e Saude, v. 22, n. 1, p. 66-75, 2017.

26. PRATA NOGUEIRA, Alex e colab. 0 estilo de vida dos universitários da Faculdade de Educação Física e Fisioterapia da UFAM. Revista Portuguesa de Ciências do Desporto, v. 2014, n. S1A, p. 689-701, 2014.

27. SALLIS, James F e colab. Progress and Challenges Progress in physical activity over the Olympic quadrennium. The Lancet, v. 388, n. 24, p. 1325-1336, 2016.

28. SALUD, Organización Mundial de La. Actividad física. Disponível em: <Acceso/Centro de prensa/Notas descriptivas/Detail>. Acesso em: 30 jul 2019.

29. SANTOS, Leianny Rodrigues Dos e colab. Análise do sedentarismo em estudantes universitários [Analysis of sedentary lifestyle among college students]. Revista Enfermagem UERJ, v. 22, n. 3, p. 416-421, 2014. Disponível em: <https://www.e-

publicacoes.uerj.br/index.php/enfermagemuerj/article/view/13768/10568>

30. SANTOS, Tiago e colab. Atividade física em acadêmicos de Educação Física: um estudo longitudinal. Revista Brasileira de Atividade Física \& Saúde, v. 22, n. 1, p. 76-84, 2017.

31. SILVA, Diego Augusto Santos e PETROSKI, Edio Luiz. Fatores associados ao nível de participação em atividades físicas em estudantes de uma universidade pública no sul do Brasil. Ciência \& Saúde Coletiva, v. 16, n. 10, p. 4087-4094, 2011

32. STEPHENS, Samantha e colab. Benefits of Physical Activity for Depression and Fatigue in Multiple Sclerosis: A Longitudinal Analysis. The Journal of Pediatrics, v. 209, p. 226- 232.e2, Jun 2019. Disponível em: <https://linkinghub.elsevier.com/retrieve/pii/S0022347619301283>. Acesso em: 1 ago 2019.

33. TOWNE, Samuel D. e colab. Accessing physical activity among young adults attending a university: The role of sex, race/ethnicity, technology use, and sleep. BMC Public Health, v. 17, n. 721, p. 1-11, 2017.

34. TURI, Bruna Camilo e colab. Low levels of physical activity and metabolic syndrome: cross-sectional study in the Brazilian public health system. Ciência \& saúde coletiva, v. 21, n. 4, p. 1043-50, 2016.

35. VARELA-ARÉVALO, María Teresa e OCHOA-MUÑOZ, Andrés Felipe e TOVAR-CUEVAS, José Rafael. Tipologías de estilos de vida en jóvenes universitarios. Rev Univ. Salud y Salud, v. 18, n. 2, p. 246-256, 2016a. Disponível em: <http://www.scielo.org.co/pdf/reus/v18n2/v18n2a06.pdf>.

36. VARELA-ARÉVALO, María Teresa e OCHOA-MUÑOZ, Andrés Felipe e TOVAR-CUEVAS, José Rafael. Tipologías de estilos de vida en jóvenes universitarios TT - Types of lifestyles in young university. Univ. salud, v. 18, n. 2, p. 246-256, 2016b.

37. VERT, Cristina e colab. Health Benefits of Physical Activity Related to an Urban Riverside Regeneration. International Journal of Environmental Research and Public Health Article, v. 16, n. 462, p. 1-18, 2019. Disponível em: <www.mdpi.com/journal/ijerph>. Acesso em: 1 ago 2019.

38. WORD HEALTH ORGANIZATION. Global Health Observatory $(\mathrm{GHO})$ data - Prevalence of insuficiente physical activity.

Page $7 / 14$ 
39. WORD HEALTH ORGANIZATION. Health topics - Actividad física.

40. WORLD HEALTH ORGANIZATION. Global action plan for the prevention and control of noncommunicable diseases 2013-2020. World Health Organization.

Geneva, Switzerland: [s.n.], 2013.

41. WORLD HEALTH ORGANIZATION. Global action plan on physical activity 2018-2030. More Active People for a Healthier World. World Health Organization.

Geneva, SW: [s.n.], 2018a. Disponível em: <http://www.who.int/publications/en/>.

42. WORLD HEALTH ORGANIZATION. Global Strategy on Diet, Physical Activity and Health - Physical Activity.

43. WORLD HEALTH ORGANIZATION. Prevalence of insufficient physical activity. Disponível em: <http://www.who.int/gho/en/>. Acesso em: 14 jul 2019.

44. YUAN, Changzheng e colab. Cycle tracks and parking environments in China: Learning from college students at peking university. International Journal of

Environmental Research and Public Health, v. 14, n. 8, 2017.

45. ZHANG, Meizhen e colab. Normal weight obesity and physical fitness in Chinese university students: An overlooked association. BMC Public Health, v. 18,

n. 1, p. 1-10, 2018.

\section{Tables}

Table 1. The sample composition indicates that Sinop had the highest percentage of participation per campus and Cuiabá had the highest absolute number of participants.

\begin{tabular}{|c|c|c|c|c|c|c|c|c|c|c|c|}
\hline \multicolumn{12}{|c|}{ Sample Demography } \\
\hline \multirow[t]{2}{*}{ Variables } & \multirow[t]{2}{*}{ Universe } & \multicolumn{10}{|c|}{ Sample } \\
\hline & & $\mathbf{n}$ & $\%$ & Fem & $\%$ & Male & $\%$ & Fre.* & $\%$ & Sen** & $\%$ \\
\hline Araguaia & 2494 & 805 & 30.59 & 476 & 59.13 & 329 & 40.87 & 209 & 25.96 & 138 & 17.14 \\
\hline Cuiabá & 10157 & 4152 & 39.89 & 2411 & 58.07 & 1741 & 41.93 & 1264 & 30.44 & 772 & 18.59 \\
\hline Rondonópolis & 3739 & 1186 & 30.94 & 670 & 56.49 & 516 & 43.51 & 351 & 29.60 & 224 & 18.89 \\
\hline Sinop & 1835 & 914 & 45.78 & 563 & 61.60 & 351 & 38.40 & 255 & 27.90 & 212 & 23.19 \\
\hline Várzea Grande & 761 & 322 & 39.82 & 122 & 37.89 & 200 & 62.11 & 121 & 37.58 & 20 & 6.21 \\
\hline TOTAL & 18986 & 7379 & 38.87 & 4242 & 57.49 & 3137 & 42.51 & 2200 & 29.81 & 1366 & 18.51 \\
\hline
\end{tabular}

* Entering $=1^{\circ}$ e $2^{\circ}$ semesters $/ * *$ Graduating $=8^{\circ}, 9^{\circ}$ e $10^{\circ}$ semesters

Table 2. Sample composition distributed per field of study among the campuses.

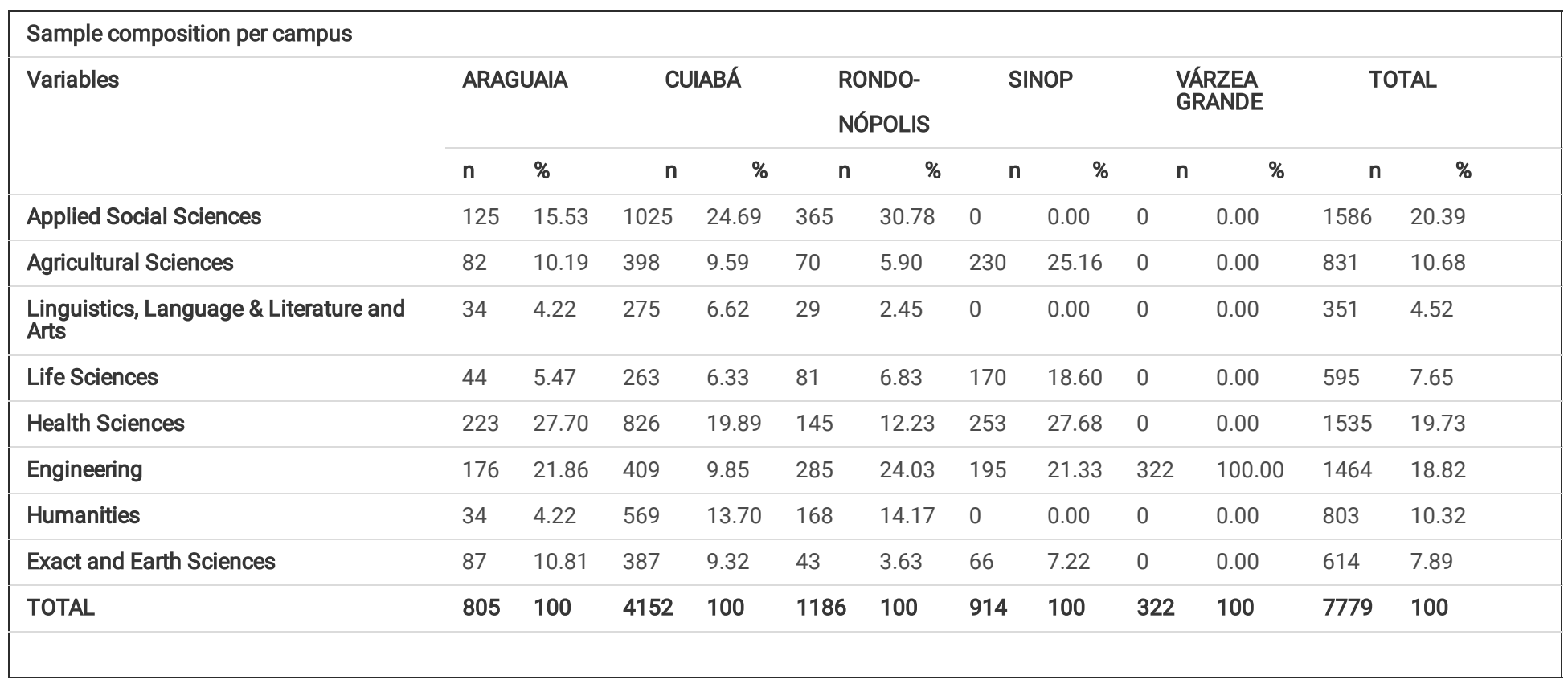

The area of Applied Social Sciences showed greater participation in the research, especially in Rondonópolis

Table 3. Number of times physical activity was performed per week. 


\begin{tabular}{|c|c|c|c|c|c|c|c|c|c|c|c|c|}
\hline \multicolumn{13}{|c|}{ Weekly physical activity profile } \\
\hline \multirow{2}{*}{$\begin{array}{l}\text { CAMPUS } \\
\text { Variables }\end{array}$} & \multicolumn{2}{|c|}{ ARAGUAIA } & \multicolumn{2}{|c|}{ CUIABA } & \multicolumn{2}{|c|}{ RONDONÓPOLIS } & \multicolumn{2}{|c|}{ SINOP } & \multicolumn{2}{|c|}{ VÁRZEA GRANDE } & \multicolumn{2}{|c|}{ TOTAL } \\
\hline & $\mathrm{n}$ & $\%$ & $\mathrm{n}$ & $\%$ & $\mathrm{n}$ & $\%$ & $\mathrm{n}$ & $\%$ & $\mathrm{n}$ & $\%$ & $\mathrm{n}$ & $\%$ \\
\hline 7 times & 47 & 5.43 & 168 & 4.13 & 59 & 4.97 & 90 & 10.43 & 12 & 3.73 & 376 & 5.15 \\
\hline 6 times & 26 & 3.01 & 89 & 2.19 & 30 & 2.53 & 88 & 10.2 & 7 & 2.17 & 249 & 3.41 \\
\hline 5 times & 78 & 9.02 & 272 & 6.69 & 64 & 5.4 & 79 & 9.15 & 23 & 7.14 & 516 & 7.06 \\
\hline 4 times & 57 & 6.59 & 243 & 5.97 & 54 & 4.55 & 45 & 5.21 & 18 & 5.59 & 417 & 5.71 \\
\hline 3 times & 107 & 12.37 & 406 & 9.98 & 108 & 9.11 & 70 & 8.11 & 35 & 10.87 & 726 & 9.94 \\
\hline 2 times & 87 & 10.06 & 451 & 11.09 & 111 & 9.36 & 106 & 12.28 & 43 & 13.35 & 798 & 10.93 \\
\hline 1 time & 99 & 11.45 & 449 & 11.04 & 112 & 9.44 & 68 & 7.88 & 42 & 13.04 & 770 & 10.54 \\
\hline 0 times & 364 & 42.08 & 1990 & 48.92 & 648 & 54.64 & 317 & 36.73 & 142 & 44.1 & 3461 & 47.38 \\
\hline Total & 865 & 100 & 4068 & 100 & 1186 & 100 & 863 & 100 & 322 & 100 & 7304 & 100 \\
\hline
\end{tabular}

There is a predominance of little physical activity.

Table 4. Number of weekly physical activity sessions for entering and graduating students.

\begin{tabular}{|c|c|c|c|c|c|c|c|c|c|c|c|c|c|c|}
\hline \multicolumn{15}{|l|}{ VARIABLES } \\
\hline CAMPUS & $\begin{array}{l}7 \\
\text { times }\end{array}$ & $\%$ & $\begin{array}{l}6 \\
\text { times }\end{array}$ & $\%$ & $\begin{array}{l}5 \\
\text { times }\end{array}$ & $\%$ & $\begin{array}{l}4 \\
\text { times }\end{array}$ & $\%$ & $\begin{array}{l}3 \\
\text { times }\end{array}$ & $\%$ & 2 & $\%$ & $\begin{array}{l}1 \\
\text { time }\end{array}$ & $\%$ \\
\hline $\begin{array}{l}\text { Araguaia } \\
\text { Entering }\end{array}$ & 8 & 3.24 & 6 & 2.43 & 45 & 18.22 & 11 & 4.45 & 22 & 8.91 & 16 & 6.48 & 30 & 12.15 \\
\hline $\begin{array}{l}\text { Araguaia } \\
\text { Graduating }\end{array}$ & 4 & 0.89 & 6 & 1.33 & 51 & 11.31 & 56 & 12.42 & 70 & 15.52 & 90 & 19.96 & 119 & 26.39 \\
\hline $\begin{array}{l}\text { Araguaia } \\
\text { Entering }\end{array}$ & 63 & 4.95 & 16 & 1.26 & 81 & 6.37 & 58 & 4.56 & 107 & 8.41 & 154 & 12.11 & 140 & 11.01 \\
\hline $\begin{array}{l}\text { Araguaia } \\
\text { Graduating }\end{array}$ & 31 & 3.97 & 23 & 2.95 & 59 & 7.56 & 56 & 7.18 & 91 & 11.67 & 84 & 10.77 & 75 & 9.62 \\
\hline $\begin{array}{l}\text { Araguaia } \\
\text { Entering }\end{array}$ & 20 & 5.57 & 12 & 3.34 & 25 & 6.96 & 11 & 3.06 & 26 & 7.24 & 32 & 8.91 & 31 & 8.64 \\
\hline $\begin{array}{l}\text { Araguaia } \\
\text { Graduating }\end{array}$ & 12 & 5.17 & 5 & 2.16 & 9 & 3.88 & 16 & 6.90 & 33 & 14.22 & 22 & 9.48 & 26 & 11.21 \\
\hline $\begin{array}{l}\text { Araguaia } \\
\text { Entering }\end{array}$ & 18 & 6.87 & 7 & 2.67 & 33 & 12.60 & 21 & 8.02 & 20 & 7.63 & 32 & 12.21 & 21 & 8.02 \\
\hline $\begin{array}{l}\text { Araguaia } \\
\text { Graduating }\end{array}$ & 9 & 4.46 & 7 & 3.47 & 13 & 6.44 & 11 & 5.45 & 29 & 14.36 & 27 & 13.37 & 15 & 7.43 \\
\hline $\begin{array}{l}\text { Várzea } \\
\text { Grande } \\
\text { Entering }\end{array}$ & 7 & 5.43 & 3 & 2.33 & 7 & 5.43 & 10 & 7.75 & 16 & 12.40 & 11 & 8.53 & 15 & 11.63 \\
\hline $\begin{array}{l}\text { Várzea } \\
\text { Grande } \\
\text { Graduating }\end{array}$ & 1 & 3.85 & 0 & 0.00 & 2 & 7.69 & 2 & 7.69 & 2 & 7.69 & 6 & 23.08 & 3 & 11.54 \\
\hline TOTAL & 173 & 4.37 & 85 & 2.15 & 325 & 8.2 & 252 & 6.36 & 416 & 10.51 & 474 & 11.97 & 475 & 1 \\
\hline
\end{tabular}

There is a greater concentration of physical inactivity among freshmen.

\section{Figures}




\section{Among Campuses}

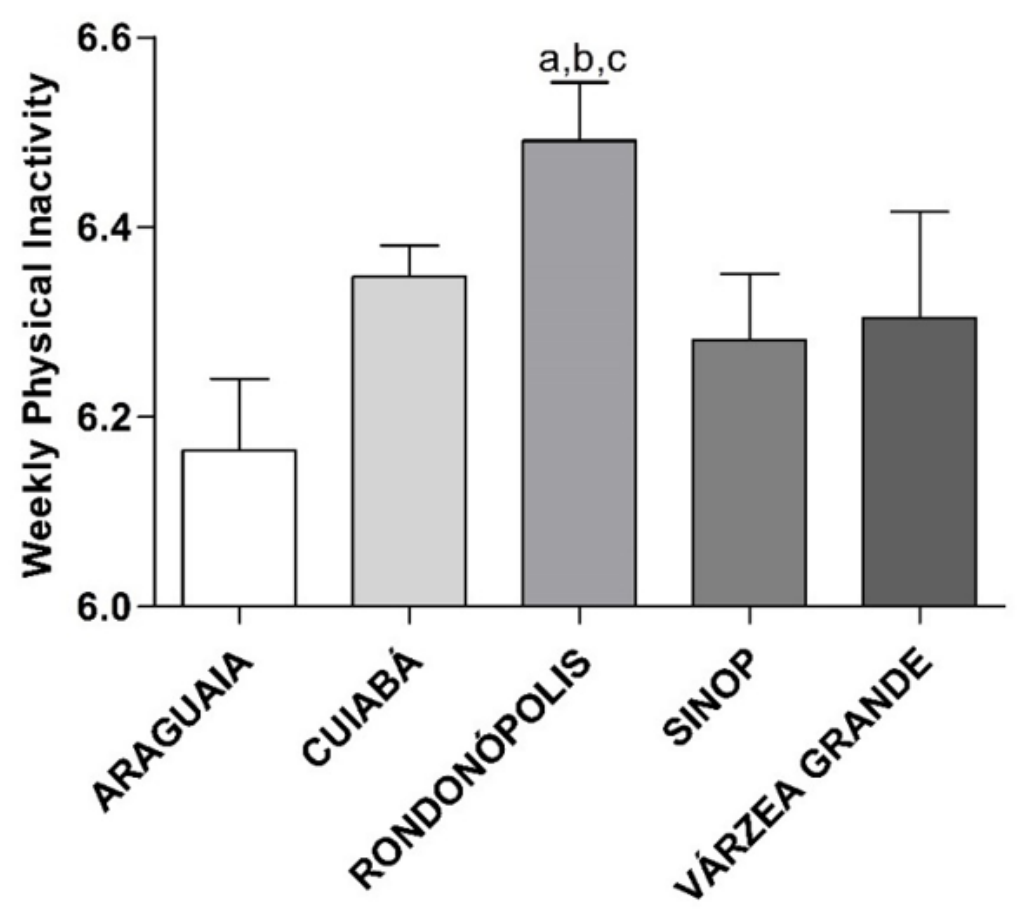

Figure 1

Comparison of physical inactivity among campuses. Students on the Rondonópolis campus had lower physical inactivity enrollment. To compare the physical inactivity, the Shapiro-Wilks normality test was performed followed by Kruskal-Wallis with Dunn's Post Hoc Test with significance of $5 \%$ was used. (A) statistically different to the Araguaia campus; (B) statistically different to the Cuiabá campus; (C) statistically different to the Sinop campus.
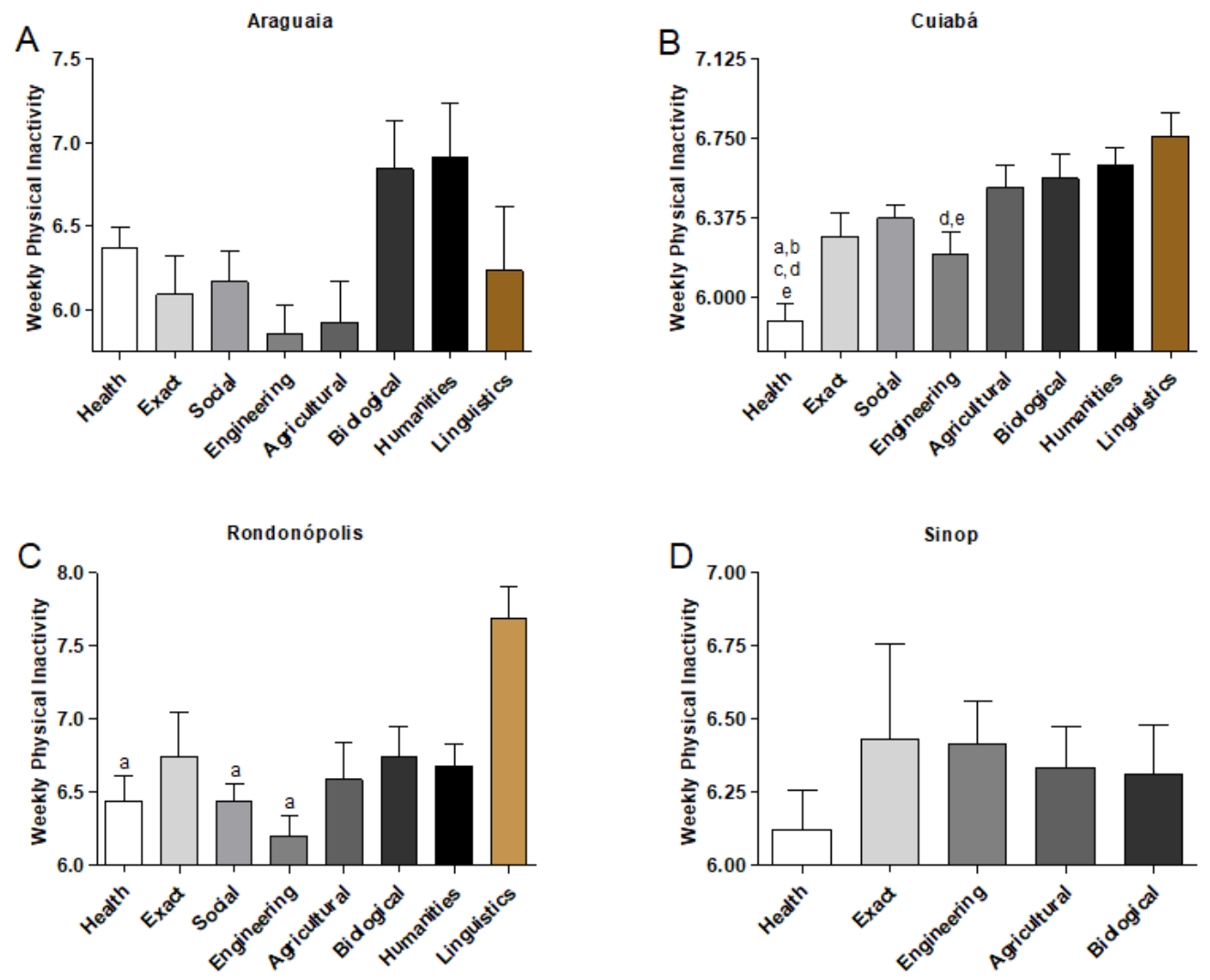
Figure 2

Weekly physical inactivity: intracampus comparison. Physical inactivity intracampus comparison in accordance with their course area. To compare the physical inactivity level among areas, first, the Shapiro-Wilks normality test followed by the Kruskal-Wallis with Dunn's Post Hoc Test with significance of $5 \%$ were performed. Fig 2B (a) difference vs Social, (b) difference vs Agricultural, (c) difference vs Biological, (d) difference vs Humanities, and (e) difference vs Linguistics; Fig 2C (a) difference vs Linguistic.
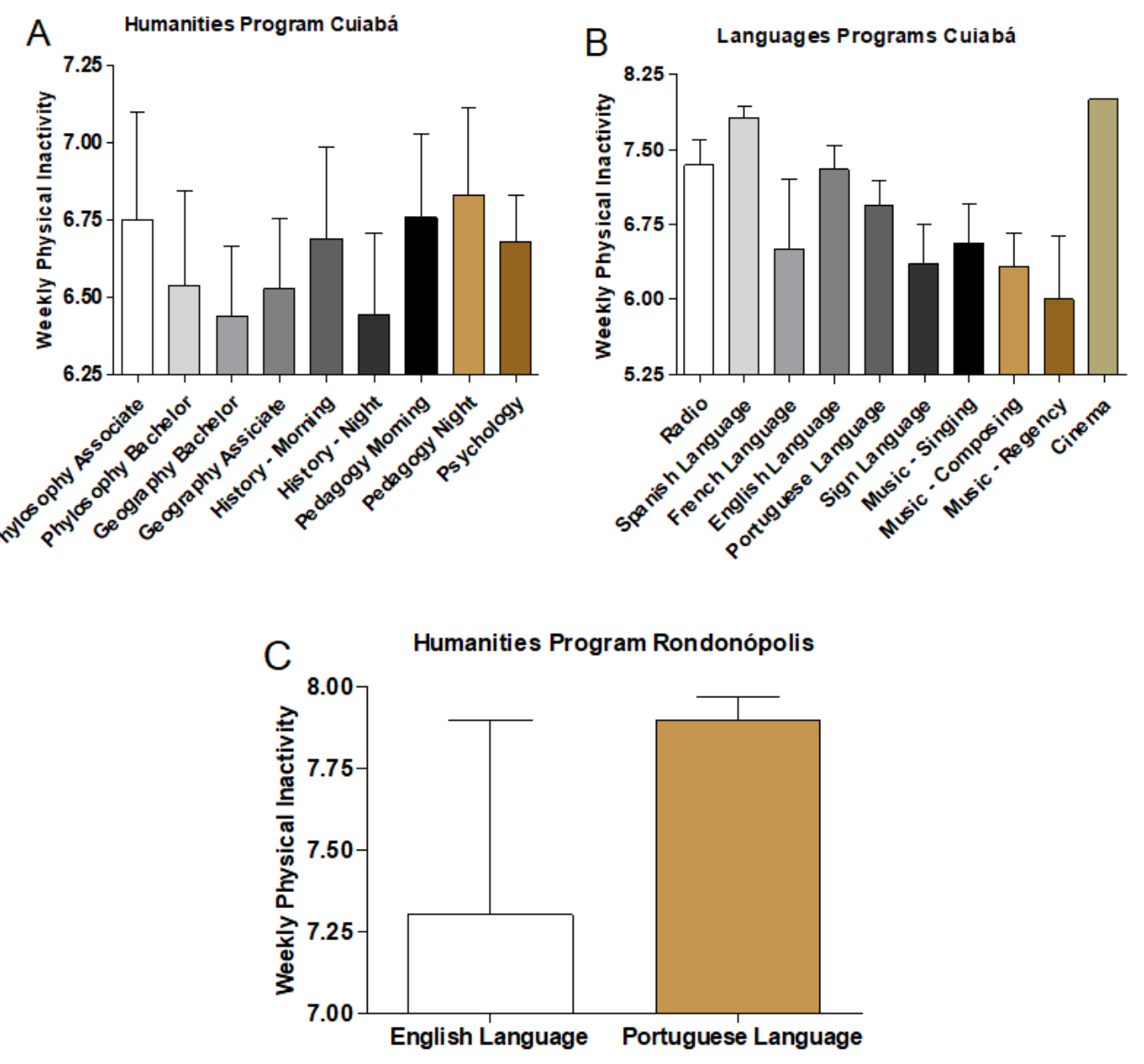

Figure 3

Weekly physical inactivity: intraprogram. No differences were noted in the weekly physical inactivity intraprogram comparison $(p>0.05)$. $(A)=$ Humanities Programs - Cuiabá; (B) Language Programs - Cuiabá; (C) Linguistics Programs - Rondonópolis. To compare the physical inactivity level, first, the ShapiroWilks normality test followed by the Kruskal-Wallis with Dunn's Post Hoc Test to Figure 2A and 2B and Mann-Whitney test, both with significance of 5\% were performed. 


\section{Students}

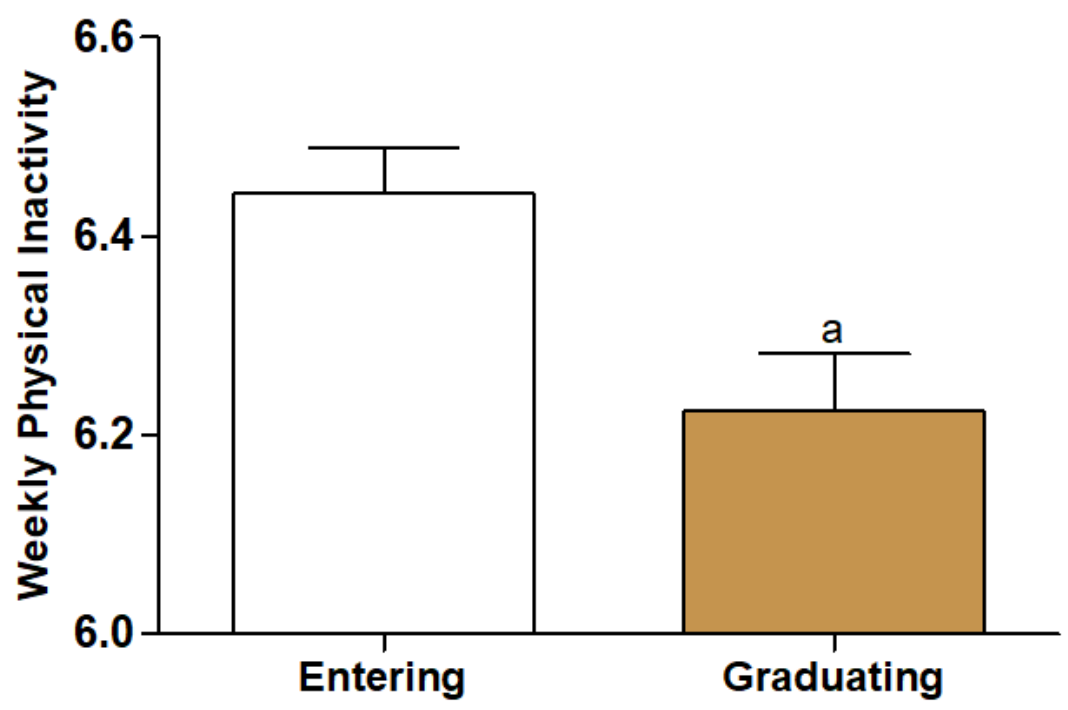

\section{Figure 4}

Weekly physical inactivity among entering and graduating students on all campuses. Graduating students of all UFMT campuses have higher physical activity when compared to entering. In the analysis of the behavior of entering and graduating students from all campuses. To compare the physical inactivity level, first, the Shapiro-Wilks normality test followed by Mann-Whitney test with significance of $5 \%$ were performed. (a) a= difference among Entering and Graduating. 

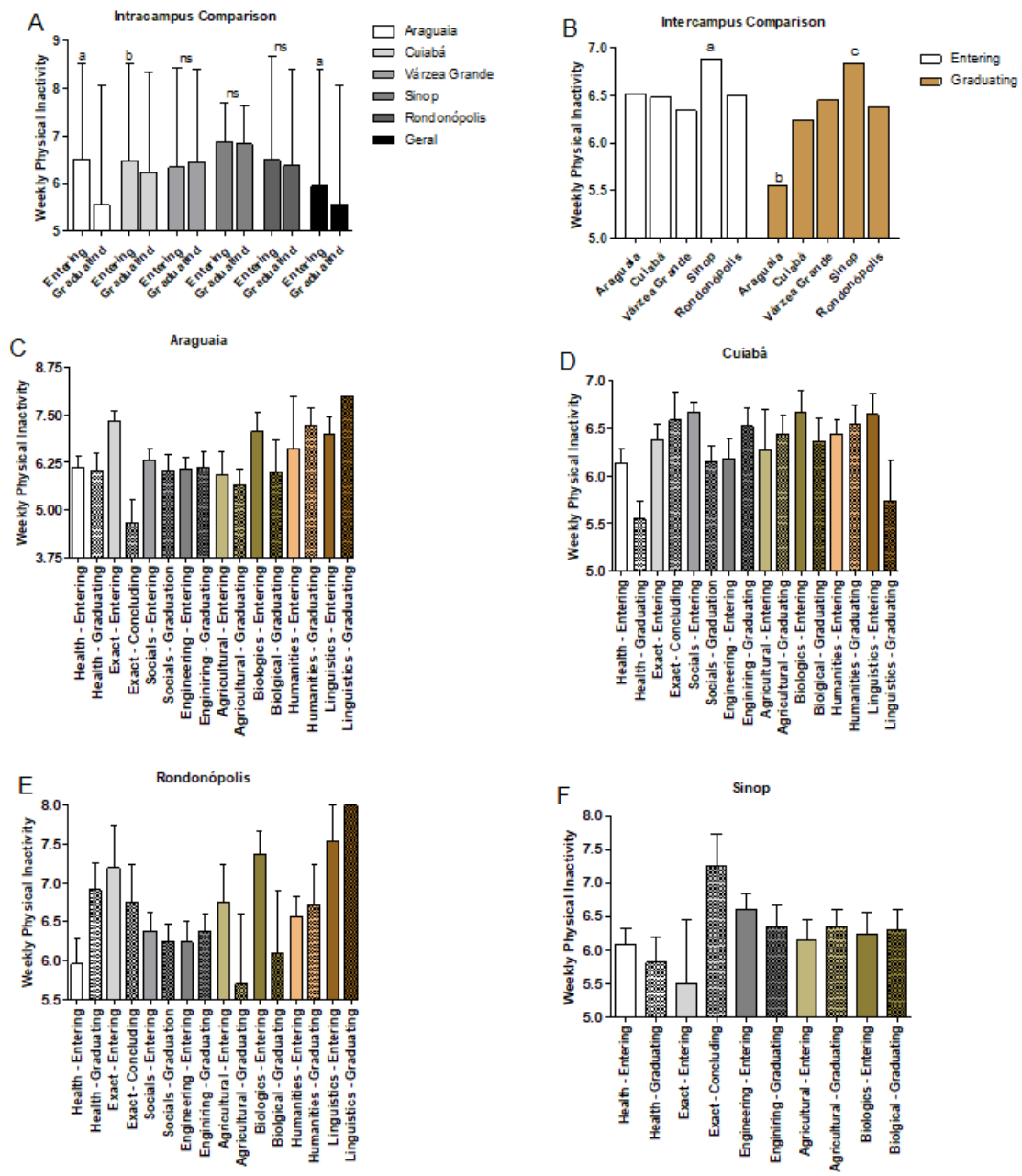

\section{Figure 5}

Weekly physical inactivity among entering and graduating students within fields of study on all campuses. The Weekly physical inactivity (A) Intracapus Comparison; (B) Intercampus Comparison, (C, D, E and F) comparison among entering and graduating students from the Araguaia, Cuiabá, Rondonópolis and Sinop Campuses respectively. To compare the physical inactivity level, first, the Shapiro-Wilks normality test followed by the Kruskal-Wallis with Dunn's Post Hoc Test. (A) a and $b=$ difference among entering and graduating; ns= no difference for significance of $5 \%$. 

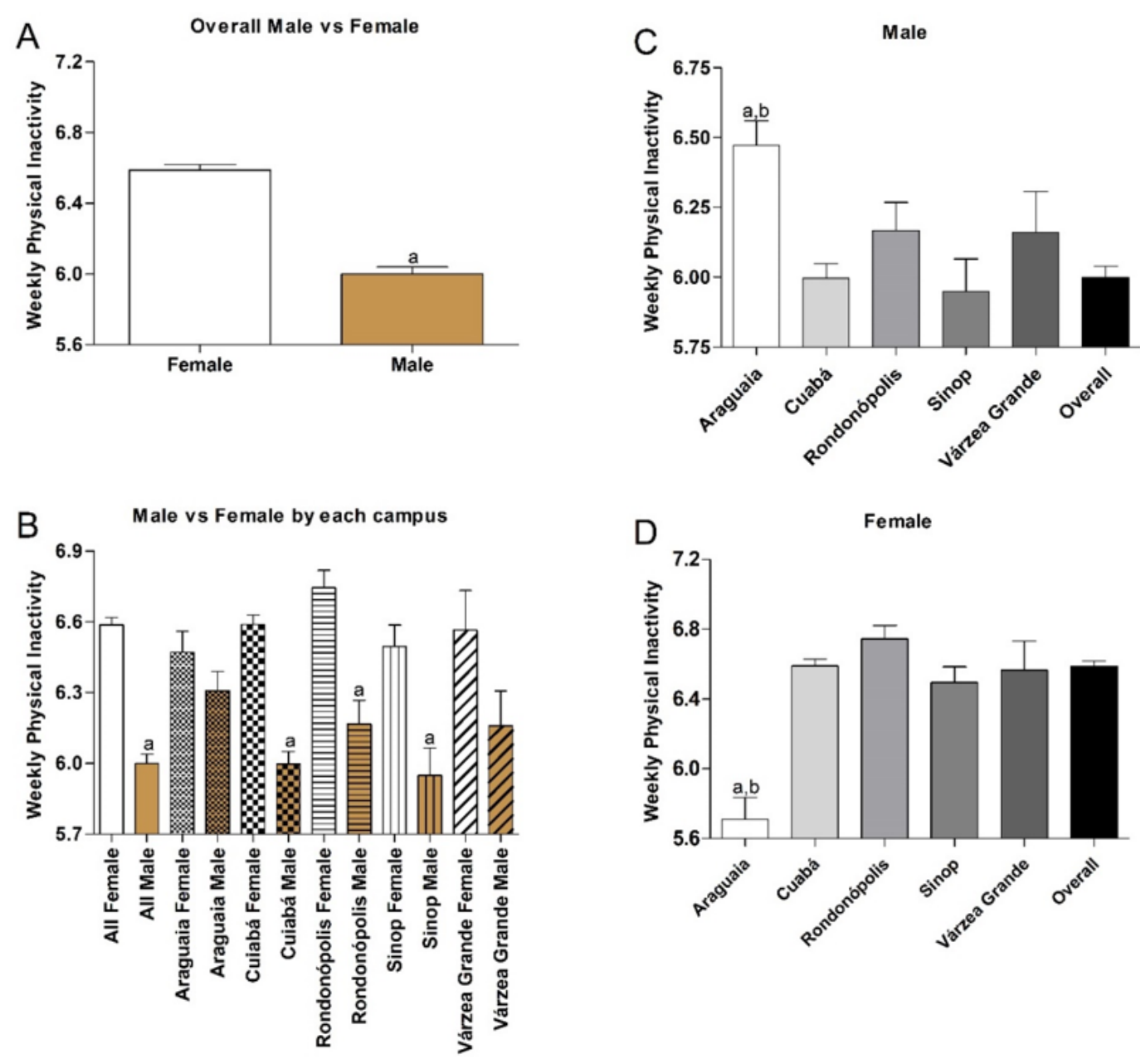

\section{Figure 6}

Weekly physical inactivity: gender comparison of all campuses. Male students have an overall higher enrollment in physical activity. (A) Comparison among female and male subjects of overall volunteers; (B) Comparison among female and male subjects separated by campus; (C) comparison among all male subjects separated by campus, and (D) comparison among all female subjects separated by campus. To compare the physical inactivity level, first, the Shapiro-Wilks normality test followed by Mann-Whitney test (Fig 6A), and Kruskal-Wallis with Dunn's Post Hoc Test. A and B a= difference among female and male, $C$ a and $b=$ difference among the campuses with a $5 \%$ significance.

\section{Supplementary Files}

This is a list of supplementary files associated with this preprint. Click to download.

- ValidatedsurveyfortheBrazilianuniversity.pdf 